\title{
FORMATION OF THE CHILD'S PERCEPTIONS OF HIS OWN FAMILY IN THE PROCESS OF FAMILY EDUCATION
}

\author{
Irina Ripka ${ }^{1}$, Larysa Klymanska ${ }^{2}$ \\ Lviv Polytechnic National University, Lviv, Ukraine \\ ${ }^{1}$ Student of master program "Social Work", of Department of Sociology and Social Work, \\ ${ }^{2}$ Doctor of Political Science (D.Sc),Professor of Department of Sociology and Social Work
}

Background: The child begins to form as a person in the family. Family is the first actor in the process of socialization of the individual. A significant part of one's being a person grows up, nurtures and functions in the environment of the family, calculates the behavior of their parents and transfers it into their adult life. The primary factors of personality formation in the family are: the degree of harmony of the married life of parents, the general perception of childhood (whether it was happy or not), the attitude of parents to children, the distribution of family roles, the way of life that parents led. In childhood, under the influence of parents, a program is laid out, which then tells you how to live, which partner to choose, how to build relationships with him, how many children and more.

Purpose: to investigate the peculiarities of family upbringing of children and to find out its influence on the formation of ideas about their own family in the process of socialization.

Methods: Theoretical research methods were set general and specific methods and techniques of scientific knowledge are used based goal, object and subject. Analysis and synthesis methods can be used to identify and understand the educational space in the context of the family-cultural space as well as the family in the context of the educational space; the historical method was used to investigate the genesis of such concepts as "family" and "fatherhood".

Results: The perceptions of the child about their own family are largely shaped by the upbringing style that is inherent in a particular family. Different styles of education: authoritarian, democratic and liberal, have different effects on a person's future choices. Therefore, the family is the environment of education and development of the child's personality. The absence of such an environment in a child's life forms a number of negative personality traits that affect a person's future.

Conclusion: The analysis of parenting behaviors in the family education process suggests that the children of Democratic parents are best socialized and have the skills to create their own ideal family model in future. Therefore, there is a need to promote this style of parental behavior in the family as the most effective, productive, psychologically safe and useful for realizing the individual characteristics of the child and forming his or her own ideas about his or her own family in the future.

Keywords: family, family-child relationships, parenting, family education, social and pedagogical system.

Дитина починає формуватися як особистість саме в сім'ї. Сім'я $є$ першим актором у процесі соціалізації особистості. Значний відрізок власного буття особистість зростає, виховується та функціонує в середовищі родини, калькує поведінку власних батьків та переносить їі у своє доросле життя. Першочерговими факторами формування особистості в сім’ї вважаються: ступінь гармонійності подружнього життя батьків, загальне сприйняття дитинства (було воно щасливим чи ні), ставлення батьків до дітей, розподіл сімейних ролей, спосіб життя, який вели батьки. Саме в дитячі роки під впливом батьків закладається програма, що підказує потім, як жити, якого партнера обрати, як будувати з ним стосунки, скільки буде дітей тощо.

Всебічний розвиток особистості можливий за умови позитивного психологічного клімату, який панує у сім’ї. Ці позитивні умови формують батьки, які виступають першими вчителями та наставниками у житті власної дитини. Якою буде сім'я дитини в майбутньому, як вона буде ставитися до своїх обов'язків у майбутній сім'ї, чи буде майбутня сім'я в радість, чи вона буде сприйматися як тягар в багатьох моментах залежить від поглядів, переконань та цінностей, котрі сформувалися про сім'ю у дитячі і молодіжні роки до власне самого часу створення своєї сім'ї.

У нормативно-законодавчій базі, зокрема у законі України «Про охорону дитинства» зазначено, що сім'я $є$ створеним природою соціальним середовищем для різнобічного 


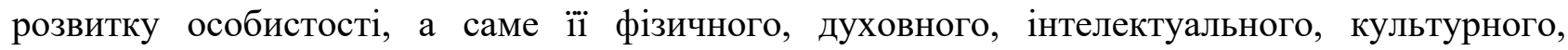
соціального розвитку, іiі фінансових та матеріальних особливостей. Сім'я несе серйозну відповідальність за життєдіяльність та створення комфортних умов для такого процесу. На обох батьків покладається рівноцінна відповідальність за розвиток, виховання і навчання дитини. Батьки, або особи, які їх замінюють, мають обов'язок і право виховувати дитину, турбуватися про їі фізичний, духовний та моральний, психологічний розвиток, цінувати гідність дитини, вчасно готувати ії до самостійної діяльності та життя.

Сьогодні сім'я опинилась в ситуації, коли їй доводиться вирішувати цілий комплекс нових проблем, у зв'язку з чим вона значною мірою втрачає здатність виконувати життєво необхідні функції та перебуває на порозі сімейної кризи та непорозумінь, що тягнуться за цим. Свідченням таких проблем в сучасній українській реальності стало збільшення кількості деструктивних сімей, в яких батьки не здатні вирішити свої власні життєві проблеми i, тим більше, не можуть забезпечити своїм дітям сприятливі умови життя і виховання. Батьки знаходяться у складній ситуації при виборі стилю поведінки у взаємодії з дітьми, що призводить до ускладнення сімейних стосунків та формування у останніх негативного образу уявлень про власну сім'ю. Більше того, в сучасній науковій літературі прийнято взагалі вживати термін «криза сім’ї», маючи на увазі ціннісний конфлікт особистості і суспільства щодо народження та соціалізації дитини, що виявляється у невиконанні нею (тобто сім'єю) репродуктивної та соціалізаційної функцій та супроводжується ослабленням сім’ї як союзу батьків і дітей (Кац, 2008, с.187).

Спеціальних досліджень, які б описували особливості процесу формування уявлень особистості про майбутню сім'ю, не виявлено, тоді як проблема є дуже важливою складовою підготовки підростаючого покоління до сімейного життя.

Таким чином, потреба в інформуванні батьків або осіб, що їх замінюють, щодо важливості правильного вибору стилю виховання дитини у сімейному середовищі та недостатня розробка в науковій літературі цієї проблеми зумовлюють актуальність цієї проблематики.

Мета: дослідити особливості сімейного виховання дітей i виявити його вплив на формування уявлень про власну сім'ю в процесі соціалізації.

Сім'я була і залишається предметом наукових досліджень як зарубіжних, так і вітчизняних педагогів, психологів, соціологів. Науково-емпіричні аспекти вивчення сім'ї, власне самого батьківства та проблеми виховання дитини у сім'ї, представлені у публікаціях сучасних соціологів і педагогів, таких як: Дж.Келлі, С.Гудман, Е.Ейдеміллер, В.Сатір, П.Ласлет, Д.Морган та ін. Науковці приділяють особливу увагу ролі сім'ї як провідного середовища виховання особистості. Саме цьому питанню присвятили свої праці Т.Алєксєєнко, Г.Авдіянц, М.Бикова, С.Голод, О.Гукаленко, А.Даник, 3. Кісарчук, О. Кляпець, В. Кравець, Т. Кравченко, Б. Ковбас, В. Костів, Т. Крюкова, О. Куфтяк, В.Савка, В. Семиченко, О. Смирнова, В.Солодников, В. Столін, Н. Уманець, О.Хромова та інші. Дослідженням стилів сімейного виховання підростаючого покоління та форму Серед сучасних дослідників над вивченням поняття сімейного виховання підростаючого покоління та формуванням уявлень дитини про власну сім'ю працювали В.Сухомлинський, М.Стельмах, Т.Демидова, І.Крупник, С.Іваненко, М.Терещенко, Т.Демидова, І.Крупник.

Отже, сім'я - середовище виховання та розвитку особистості дитини. Відсутність такого середовища у житті дитини формує низку негативних якостей особистості, що впливають на майбутне людини.

Формування та соціалізація дитячої особистості відбувається під впливом, перш за все, об'єктивних умов сімейного життя (а саме, структури і складу сім’і, зразків поведінки батьків, структури влади, авторитету і лідерству, рольової поведінки, індивідуальних особливостей членів сім’і, очікувань і установок, характеру і структури сімейного спілкування), а по-друге цілеспрямованого виховання. Саме виховання сприяє процесу засвоєння дитиною соціально схвалених нормативів поведінки, впливає на їі спроможність сприймати стихійні впливи соціального середовища, стимулює засвоєння позитивного прикладу. 
Кожна сім'я демонструє дитині різноманітні форми сімейних взаємин: між батьками і дітьми; між батьками та родичами; між батьками та сусідами; шлюбні стосунки між чоловіком і дружиною; стосунки з оточуючим соціальним простором та інші. Варто наголосити, що сім'я - це соціальний простір, в якому проходить значна частина життя дитини, де в різні періоди вона виявляє себе в різних соціальних ролях та засвоює різноманітні види проекцій взаємостосунків, що відповідають цим ролям.

Життєдіяльність сім'ї відбувається в процесі реалізації їі основних функцій, а саме: репродуктивної (продовження людського роду); комунікативної (побудова здорового психологічного клімату, взаємної допомоги та підтримки; комунікація в межах сім'ї та у середовищі відкритого соціуму); виховної (закладення фундаменту формування здорової особистості та формування навичок успішної соціалізації дитини); матеріально-економічної (матеріально-технічна база; рівень прибутковості обох членів сім'ї, або людей, які їх замінюють); житлово-побутової (забезпеченість якісним житлом, ведення домашнього господарства, організація побуту); рекреативної (організація культурного дозвілля, відпочинку та просвітництва). Через ці функції сім'я пов'язана з суспільством/соціумом та 3 особистістю на загал. Вищезазначені функціональні обов'язки сім’ї мають просоціальний характер і можуть розглядатися як види життєдіяльності сім’ї, що забезпечують необхідні вимоги соціуму, власне особисті, потреби кожного з членів сім’ї, сімейні та індивідуальні (групові) потреби людини.

Виховна функція сім’ї забезпечується шляхом задоволення особистих потреб дорослих їі членів у батьківстві та материнстві, взаєминах з дітьми, їхньому вихованню, самореалізації батьків у дітях. Змістовна реалізація цієї функції сім’ї забезпечує соціалізацію молодого покоління, його підготовку до майбутнього життя та формування уявлень дитини про власну сім’ю. Складовою цієї виховної функції можна вважати емоційну підтримку, яка включає в себе відчуття емпатії один до одного, психологічний захист та обмін власними переживаннями кожного члена сім'ї. Духовне спілкування, яке так само можна вважати складовою виховної функції сім'ї, включає в себе культурну складову, передбачає забезпечення потреб в соціальній дозвіллєвій діяльності та взаємному духовному та культурному збагаченні. Всі функції, притаманні сім'ї, реалізуються нею комплексно. При цьому зміна активності в будьякому одному функціональному напрямі викликає зміни активності в інших функціональних аспектах. Однак такий взаємовплив не є однозначним. Виховний потенціал сім’і - це виховні можливості сім’ї, її здатність виконувати виховну функцію (Арутюнянц, 2008, с.128).

Сучасні російські дослідники (А.Мудрик, О.Зверева, Т.Куликова) зазначають наступні фактори сімейного виховання, які безпосередньо мають вплив на функціонування дитини в майбутньому і побудову її уявлень про власну сім'ю:

1. Соціально-економічний. Описує матеріальну сторону сім'ї, рівень іiі фінансових можливостей та трудову зайнятість дорослих членів сім'ї.

2. Техніко-гігієнічний. Зазначає житлово-побутові умови сім’ї, технічне забезпечення житла, особливості, що характеризуються місцем знаходження населеного пункту (мегаполіс, місто, селище).

3. Демографічний. Характеризує структуру і склад сім'ї: повна, неповна, материнська, складна, проста, однодітна, багатодітна.

4. Соціально-культурний. Він включає освіту батьків, їхній інтелектуальний і культурний рівень, психолого-педагогічну компетентність та мікроклімат сім'ї.

На думку Т.Кравченко фактори, що впливають у сім’ї на формування поглядів та навичок особистості дитини, доцільно розділити в такий спосіб: соціальний мікросоціум, в якому дитина залучається до соціальних ролей та формує власні ціннісні орієнтації, починає розуміти складність і суперечності сучасного суспільства; внутрішня і позасімейна життєдіяльність, що є адекватним способом залучення дитини до майбутньої життєдіяльності; власне процес сімейного виховання, де очевидно йде мова про набір конкретних педагогічних впливів (Кравченко,2006, с.142).

Потужний вплив на зміст сімейного виховання, на думку Т.Кравченко, має характер домінування - система відносин влади й підпорядкування. Влада в сім'ї детермінує керівництво 
й організацію іï функціонування, особливості прийняття рішень, міру участі членів сім'ї в управлінні їі життєдіяльністю. Пріоритетну роль у визначенні суб'єкта домінування відіграють такі чинники, як матеріальне забезпечення сім”і, планування сімейного бюджету, «психотерапевтична» функція, виховання дітей (Кравченко Т.,2006, с.150) Існування родини, зокрема сім'ї, як соціального інституту залежить від способів розв'язання проблем комунікації, як індивідуальної, так і групової, тобто - особливостей спілкування між членами сім’ї, способів вирішення конфліктів, умов міжгрупової взаємодії як побудови відносин з соціальним оточенням тощо. Взаємодія між кількома особами у сім’ї має на меті взаємообмін отриманою інформацією, співвідношення зусиль і реалізації батьківських функцій у спільній діяльності, встановлення та розвиток міжособистісних взаємин батьківський стиль поведінки $є$ одним із найменш досліджуваних аспектів батьківсько - дитячих стосунків. Під батьківським стилем поведінки розуміють систему або сукупність батьківського емоційного ставлення до дитини, сприйняття дитини і способів поведінки 3 нею. Поняття «батьківський стиль» чи «стиль виховання» використовується для визначення установок та відповідної поведінки, що не пов'язано саме 3 конкретною дитиною, а характеризує ставлення до дітей взагалі. У спеціалізованій літературі досить широко описані феноменологія батьківських стосунків, стилі поведінки, а також їхні наслідки - формування індивідуальних особливостей дитини, що проявляються в нормальній чи аномальній поведінці (Дружинин, 1996, с.15).

Д.Бомрінд (американський психолог) виокремлює авторитарний, демократичний та ліберальний стилі виховання дітей у сім'ї. Авторитарний стиль, який застосовують батьки в процесі виховання власних дітей характеризується високим рівнем батьківського контролю. Батьки керуються наказами та вимагають негайного їх виконання без попереднього обговорення. Стосунки між батьками та дітьми закриті для постійного спілкування, навіть холодні. В такій сім'ї для дитини жорсткі вимоги та правила, не допускають їх обговорення. При такому стилі поведінки батьків, діти важче соціалізуються, боязкі, похмурі, залякані та дратівливі. Така родина вирізняється вимогливістю та заборонами у ставленні до дітей. При порушенні дітьми вимог 3 боку батьків часто використовуються фізичні покарання. Дитина в такій родині самотня, невпевнена, невротична. Демократичний стиль виховання дітей у сім'ї характеризується високим рівнем прийняття дитини, добре розвиненою системою обговорення проблем дитини, інтенсивним спілкуванням з нею, вірою в її самостійність водночас із готовністю за необхідності прийти на допомогу. За такого виховання діти вирізняються вмінням спілкуватися з однолітками; активністю, агресивністю, намаганням контролювати інших дітей (але самі уникають контролю), добрим фізичним розвитком. Ліберальний стиль батьківської поведінки характеризується неналежним рівнем батьківської комунікації та перевірки. Переважна кількість батьків, які застосовують цей стиль виховання, залюблюють дитину вседозволеністю, вони не контролюють ні часу прогулянок, ні виконання завдань. У даному випадку між батьками та дітьми стосунки теплі та відкриті. Батьки відкриті для спілкування 3 дітьми, однак домінуюча спрямованість комунікації - від дитини до батьків. Дітям надана необмежена свобода за умови незначного, ситуативного керівництва з боку батьків. Відсутність чітких обмежень у поведінці дітей призводить до їхньої неслухняності та агресивності. У присутності сторонніх вони поводять себе неадекватно та імпульсивно. У такій родині панує принцип вседозволеності. Поступово формується незадоволений всіма навколишніми конфліктний егоїст, який не вміє вступати в позитивні взаємини з іншими людьми (Соціалізація особистості, 2011, с.427).

Аналіз стилів батьківської поведінки у процесі сімейного виховання дозволяє стверджувати, що найкраще соціалізуються і мають навички створення власної ідеальної моделі у сім'ї в майбутньому, діти демократичних батьків. Тому власне виникає потреба популяризувати саме цей стиль батьківської поведінки в сім'ї як найбільш ефективний, продуктивний, психологічно безпечний та корисний для реалізації індивідуальних особливостей дитини та її формування уявлень про власну сім'ю у майбутньому часі.

Таким чином, доцільно наголосити, що процес сімейного виховання є однією з необхідних ланок виховання дитини, яка містить у собі можливі проекції сімейних відносин на майбутнє дитини та іiі сім’ї. Під проекцією сімейних відносин маємо на увазі неусвідомлені, 
неконтрольовані впливи (манера поведінки, звички, спосіб життя тощо), які систематично або регулярно повторюються і впливають на дитину, формуючи ії погляди, орієнтації, уявлення. Саме спосіб сімейного виховання виступає конкретною змістовною соціально-психологічною формою організації життєдіяльності сім’і і справляє домінуючий вплив на формування особистості дитини та ії уявлення про власну сім’ю.

\section{References}

Arutyunyants E. (2008) Pedagogical potential of the family and the problem of social infantilism of the youth // Father in the Modern Family;

Bertho D. (2006) Family intergenerational transmissions: the experience of comparative analysis // Psychoanalysis and the science of man. (P.139-152) - M .: Progress;

Druzhinin V. (1996) Psychology of the family. - M .: KSP;

Katz MN (2008) Modern Ukrainian Family: Crisis or Modernization? // Questions of spiritual culture. Philosophical Sciences. - Access mode: http://dspace.nbuv.gov.ua/bitstream / handle $/ 123456789 / 65029 / 37$-ac.pdf?sequence=1)

Kravchenko T. (2006) The upbringing potential of the family in modern conditions // Social Psychology (p.142-150) - № 2 (16);

Socialization of personality: culture, educational policy, technologies of formation: materials of the international. Research Practice Conf. young scientists and students., April 20-21. 2011, the city of Sumy / [editorial: O. Yu. Shcherbin-Yakovlev (ed.), Etc.] - Sumy: Issue of the SSUU. A. S. Makarenko, 2011.

\section{Список використаних джерел}

Арутюнянц Э.(2008) Педагогический потенциал семьи и проблема социального инфантилизма молодежи // Отеи в современной семье;

Берто Д. (2006) Семейные межпоколенные трансмиссии: опыт сравнительного анализа // Психоанализ и наука о человеке.(c.139-152) - М.: Прогресс;

Дружинин В. (1996) Психология семьи. - М.: КСП;

Кац М.Н. (2008) Современная украинская семья: кризис или модернизация? // Bonросы духовной культуры. Философские науки. - Режим доступа : http://dspace.nbuv.gov.ua/bitstream /handle /123456789/65029/37-ac.pdf?sequence=1)

Кравченко Т.(2006) Виховний потенціал сім'ї в сучасних умовах // Соціальна психологія.(с.142-150) - № 2(16);

Соціалізація особистості: культура, освітня політика, технології формування : матеріали міжнар. наук.-практ. конф. молодих учених і студ., 20-21 квіт. 2011 р., м. Суми / [редкол.: О. Ю. Щербина-Яковлева (відп. ред.) та ін.] - Суми : Вид-во СумДПУ ім. А. С. Макаренка, 2011.

\section{Contact information:}

Ірина Ріпка irapeleh812@gmail.com

Лариса Климанська

Larysa_kl@ukr.net 